\title{
PENERAPAN MODEL PEMBELAJARAN LSQ UNTUK MENINGKATKAN KEAKTIFAN DAN HASIL BELAJAR ILMU STATIKA BANGUNAN PROGRAM KEAHLIAN TGB SMKN BINAAN PROVINSI SUMATERA UTARA
}

\author{
Mutmainnah Sitorus ${ }^{1}$, Nono Sebayang ${ }^{2}$ \\ ${ }^{1}$ Alumni Program Studi Pendidikan Teknik Bangunan, Fakultas Teknik UNIMED \\ ${ }^{2}$ Dosen Pengajar Jurusan Pendidikan Teknik Bangunan, Fakultas Teknik UNIMED \\ (sby_nono@yahoo.co.id)
}

\begin{abstract}
ABSTRAK
Tujuan dari penelitian ini adalah untuk meningkatkan keaktifan dan hasil belajar pada mata pelajaran Ilmu Statika Bangunan Siswa Kelas X Program Keahlian Teknik Gambar Bangunan SMKN Binaan Provinsi Sumatera Utara dengan menerapkan Model Pembelajaran Learning Start With A Question. Penelitian ini merupakan penelitian tindakan kelas yang dilakukan pada semester genap tahun ajaran 2015/2016 dengan jumlah siswa 22 orang. Berdasarkan hasil evaluasi dan kriteria keberhasilan yang telah ditetapkan dalam penelitian ini ditemukan siklus I nilai rata-rata keaktifan siswa meningkat yaitu 67,23 menjadi 87,88 pada siklus II. Sedangkan nilai rata-rata hasil belajar siswa siklus I meningkat yaitu 69,09 ketercapaian kelas $64 \%$ menjadi 87,88 ketercapaian kelas $75 \%$ pada siklus II. Hasil penelitian menunjukkan penerapan Model pembelajaran Learning Start With A Question dapat meningkatkan keaktifan dan hasil belajar siswa pada mata pelajaran Ilmu Statika Bangunan.
\end{abstract}

Kata Kunci : Hasil Belajar, Keaktifan, Learning Start With A Question

\begin{abstract}
The purpose of this research is to improve the activated and outcomes learning in subject Science Statics Building Student Class X Programe Expertise Of Engineering Picture Building SMKN Binaan By Applying The Type Learning Start With A Question. This research is a classroom action research conducted in the second semester of academic year 2015/2016 with the number of students are 22 people. Based on the evaluation and success criteria that have been established of this research, found the first cycle the average value of activated student increase 67,23 become 87,88 on the second cycle. While the average value of the outcames learning on the first cycle increase that 69,06 achievement of class $64 \%$ become 87,88 achievement of class $75 \%$ on the second cycle. The result showed the application of Type Learning Start With A Question mode can improve activated and outcomes learning of student in subject Science Statics Building.
\end{abstract}

Keywords: Activated, Learning Start With A Question, Outcames Learning 


\section{Pendahuluan}

Pendidikan merupakan salah satu faktor yang sangat penting bagi kehidupan manusia. Dengan pendidikan sumber daya manusia yang berkualitas akan dapat terwujud. Untuk mencapai sumber daya yang berkualitas mutu pendidikan harus ditingkatkan. Dalam mencapai mutu pendidikan yang lebih baik, tentunya tidak akan terlepas dari upaya peningkatan kualitas pembelajaran disekolah, misalnya dengan penataran guru, penyedian buku paket, serta penyempurnaan kurikulum. Tujuan pendidikan pada dasarnya adalah mengantar para siswa menuju pada perubahanperubahan tingkah laku intelektual, moral, maupun sosial.

Dalam upaya peningkatan mutu pendidikan, maka pemerintah membuka Sekolah Menengah Kejuruan (SMK) dengan berbagai macam kompetensi keahlian. Sekolah Menengah Kejuruan (SMK) merupakan suatu lembaga pendidikan formal dalam bidang kejuruan yang diharapkan mampu menghasilkan lulusan yang berakhlak mulia, produktif, kreatif, inovatif serta mampu menjawab segala tuntutan dunia kerja sesuai dengan bidangnya masing-masing.

SMK Negeri Binaan Provinsi Sumatera Utara merupakan salah satu lembaga pendidikan formal yang memiliki jurusan Teknik Gambar Bangunan dengan program keahlian Teknik Gambar Bangunan. Salah satu mata pelajaran produktif pada Teknik Gambar Bangunan (TGB) adalah Ilmu Statika Bangunan. Mata pelajaran Ilmu Statika Bangunan.

Berdasarkan observasi penulis di SMK Negeri Binaan Provinsi Sumatera Utara pada tanggal 9 Juni 2015, dapat dilihat Nilai Ujian Harian bahwa pada tahun pelajaran 2012-2013 dari jumlah siswa 27 orang diperoleh siswa yang sangat kompeten $7,41 \%$, siswa yang kompeten $14,81 \%$, siswa yang cukup kompeten $18,51 \%$ dan siswa yang kurang kompeten 59,26\%. Pada tahun pelajaran 2013-2014 dari jumlah siswa 23 orang diperoleh siswa yang sangat kompeten $8,7 \%$, siswa yang kompeten $8,7 \%$, siswa yang cukup kompeten $34,78 \%$ dan siswa yang kurang kompeten 47,82\%. Dan pada tahun terakhir hasil belajar siswa masih belum mendapatkan peningkatkan, dari jumlah siswa 24 orang diperoleh siswa yang sangat kompeten 4,17\%, siswa yang kompeten 12,5\%, siswa yang cukup kompeten $29,17 \%$ dan siswa yang kurang kompeten 54,16\%.

Hal ini disebabkan karena terjadinya sebuah masalah dalam proses belajar mengajar, dimana setelah melakukan observasi dapat dilihat masalah yang terjadi yaitu: rendahnya keaktifan dan hasil belajar Ilmu Statika Banguna siswa. Oleh karena hal tersebut, peneliti berupaya untuk meningkatkan keaktifan dan hasil belajar siswa dengan mencoba penerapan model pembelajaran baru didalam kelas, yaitu model pembelajaran Learning Starts With A Question (LSQ), merupakan suatu model pembelajaran aktif dalam bertanya.

Rumusan masalah penelitian ini adalah : Untuk mengetahui apakah penerapan model pembelajaran LSQ dapat meningkatkan keaktifan dan hasil belajar siswa pada mata pelajaran Ilmu Statika Bangunan Program keahlian TGB SMK Negeri Binaan Provinsi Sumatera Utara Tahun Pelajaran 2015/2016?

Penelitian ini dilakukan bertujuan : Untuk mengetahui peningkatan keaktifan dan hasil belajar siswa dengan menerapkan model pembelajaran LSQ pada mata pelajaran Ilmu Statika Bangunan Program keahlian TGB SMK Negeri Binaan Provinsi Sumatera Utara Tahun Pelajaran 2015/2016.

\section{Kajian Teori}

Keaktifan berasal dari kata aktif yang artinya giat bekerja, giat berusaha, mampu bereaksi dan beraksi. Menurut Kamus Besar Bahasa Indonesia (KBBI), Keaktifan adalah kegiatan/aktivitas. Keaktifan dapat digolongkan menjadi keaktifan jasmani dan keaktifan rohani, dimana keduanya harus dihubungkan. Sedangkan belajar adalah suatu proses yang melibatkan interaksi antara guru (pemberi informasi) dan siswa (penerima) sehingga tercapainya suatu tujuan pembelajaran. Maka dapat disimpulkan bahwa keaktifan merupakan segala kegiatan yang dilakukan dalam proses interaksi antara guru dan siswa atau siswa dengan siswa lain dalam rangka mencapai tujuan belajar.

Hasil belajar merupakan gambaran tingkat penguasaan terhadap sesuatu yang dipengaruhi di dalam proses belajar mengajar 
setelah dilakukan evaluasi. Oemar Hamalik (2004:30) menyatakan bahwa: "Bukti sesorang telah belajar ialah terjadinya perubahan tingkah laku pada diri orang tersebut, misalnya dari tidak tahu menjadi tahu, dan dari tidak mengerti menjadi mengerti ". Ini berarti hasil belajar dari seseorang yang telah melakukan perbuatan belajar maka akan terlihat dari tingkat pengusaan dan perubahan tingkah lakunya. Pada penelitian ini, hasil belajar yang ingin penulis teliti adalah hasil belajar mata pelajaran Ilmu Statika Bangunan pada kompetensi dasar membuat diagram gaya normal, gaya lintang, momen, dan menerapkan teori keseimbangan, karna melihat dari masalah keberhasilan hasil belajar siswa yang rendah dan masih banyaknya siswa yang memperoleh nilai dibawah KKM (kriteria ketuntasan minimal). Adapun materi pokok dari kompetensi dasar tersebut adalah kondisi kesetimbangan, diagram gaya normal, gaya lintang, dan momen. Hasil belajar Ilmu Statika pada kompetensi pengetahuan diukur dengan menggunakan tes pilihan berganda 4 opsi.

Model learning start with a question adalah suatu model pembelajaran aktif dalam bertanya. Agar siswa aktif dalam bertanya, maka siswa diminta untuk mempelajari materi yang akan dipelajarinya, yaitu dengan membaca terlebih dahulu. Dengan membaca maka siswa memiliki gambaran tentang materi yang akan dipelajari sehingga apabila dalam membaca atau membahas materi tersebut terjadi kesalahan konsep akan terlihat dan dapat dibahas serta dibenarkan secara bersamasama. Adapun langkah-langkah dari model pembelajaran LSQ adalah (1) Menentukan dan membagikan materi yang akan dipelajari, (2) Meminta kepada siswa untuk mempelajari materi bersama teman sebangkunya, (3) Meminta kepada siswa untuk memberikan tanda pada bagian yang tidak dipahami, dan membahas poin-poin yang telah diberi tanda, (4) Membagi kelas menjadi beberapa kelompok yang beranggotakan 4 sampai 5 orang, (5) Meminta siswa untuk mendiskusikan pertanyaan yang akan ditulis mengenai materi yang telah dibaca, (6) Mengumpulkan pertanyaan - pertanyaan yang telah ditulis oleh siswa, dan (7) Menyampaikan materi pelajaran dengan menjawab pertanyaan-pertanyaan yang dibuat siswa.

Model yang digunakan guru dalam penyampaian materi pelajaran sangat mempengaruhi keberhasilan proses pembelajaran. Guru harus mampu menerapkan model pembelajaran yang tepat sesuai dengan karakteristik dan tujuan pembelajaran. Mata pelajaran Ilmu Statika Bangunan menuntut keaktifan siswa dalam proses pembelajaran. Siswa harus berperan aktif terutama dalam mengajukan pertanyaan - pertanyaan yang tidak dipahami. Peran aktif siswa dalam proses pembelajaran harus menjadi fokus utama dalam perbaikan model pembelajaran

Ada penelitian yang telah dilakukan mengenai model pembelajaran LSQ dalam rangka meningkatkan keaktifan dan hasil belajar siswa. Dalam penelitian tersebut dinyatakan bahwa adanya peningkatan keaktifan dan hasil belajar siswa melalui penerapan model pembelajaran LSQ. Salah satu penelitian yang telah dilakukan yaitu : Penelitian Wirdayanti Syafura (2014) dalam penelitiannya, mengungkapkan bahwa penerapan strategi pembelajaran Learning Start With A Question dapat meningkatkan hasil belajar siswa yaitu dari $68 \%$ pada siklus I menjadi $87 \%$ pada siklus II. Dan penerapan strategi pembelajaran Learning Start With A Question juga dapat meningkatkan aktivitas siswa yaitu dari $69 \%$ pada siklus I menjadi $82 \%$ pada siklus II.

\section{Metodologi Penelitian}

Penelitian tindakan kelas (PTK) ini dilaksanakan di SMK Negeri Binaan Provinsi Sumatera Utara. Penelitian ini dilaksanakan di semester genap tahun ajaran 2015/2016. subjek penelitian ini adalah siswa kelas X SMK Negeri Binaan Provinsi Sumatera Utara pada Program Keahlian Teknik Gambar Bangunan.

Penelitian ini dilakukan dalam dua siklus, dimana pada setiap siklus tahapan yang dilakukan yaitu :

a. Perencanaan Tindakan (Planning) pada tahap ini, peneliti bekerjasama dengan guru mata pelajaran Ilmu Statika Bangunan untuk menemukan pokok bahasan dan menyiapkan perangkat pembelajaran berbentuk silabus dan rencana pelaksanaan pembelajaran (RPP). Kemudian peneliti menyusun tes. Selanjutnya peneliti membuat lembar observasi untuk melihat keaktifan siswa.

b. Pelaksanaan Tindakan (acting) dalam tahap ini, peneliti melakukan pre-tes. Setelah itu, pembelajaran dimulai dengan memperkenalkan materi pelajaran sesuai 
dengan RPP yang telah disusun sebelumnya dengan menggunakan tindakan penerapan model pembelajaran LSQ. Setelah tindakan selesai dilakukan evaluasi belajar dengan memberikan tes pilihan berganda. Pada tahap ini peneliti langsung mengawasi dan membimbing siswa serta memberikan penjelasan yang perlu jika terdapat kesulitan-kesulitan yang dialami siswa dalam proses pembelajaran.

c. Pengamatan (Observing). Observasi yang dilakukan merupakan pengamatan terhadap keaktifan siswa selama proses belajar mengajar yang dilakukan oleh rekan peneliti yang mengambil posisi dibelakang siswa, dengan menerapkan model pembelajaran LSQ.

d. Refleksi (Reflecting) pada tahap refleksi ini, hasil yang diperoleh dari tahap pelaksanaan tindakan dan observasi dikumpulkan dan dianalisis, sehingga diperoleh kesimpulan dari tindakan yang telah dilakukan.Pada tahapan ini, jika hasil belajar meningkat apabila telah memenuhi Kriteria Ketuntasan Minimum $(\mathrm{KKM}) \geq 75$, maka penerapan model pembelajaran LSQ dalam penelitian ini dikatakan mengalami peningkatan atau berhasil. Dan apabila sebaliknya maka ini akan menjadi pertimbangan untuk melakukan siklus selanjutnya.

Tes yang digunakan peneliti adalah tes objektif. Sebelum dilakukan Uji coba instrumen tes objektif ini berjumlah 50 soal dengan empat option, dimana 25 soal untuk siklus I dan 25 soal untuk siklus II. Namun setelah dilakukan uji coba instrumen, tes objektif berbentuk pilihan berganda menjadi sebanyak 41 soal dengan empat option pilihan, dimana 20 soal untuk siklus I dan 21 soal untuk siklus II, yang digunakan untuk memperoleh data hasil belajar pada kompetensi yang ditentukan. Adapun teknik analisis untuk hasil belajar siswa adalah sebagai berikut :

$$
\text { Nilai }=\frac{\text { Nilai yang diperoleh siswa }}{\text { Jumlah Siswa }} \times 100 \%
$$

Berdasarkan Standart Ketuntasan Belajar Minimal (SKBM) yang ditetapkan dalam kompetensi dasar pada penelitian tindakan ini, maka seorang siswa telah dikatakan mencapai kompetensi jika siswa memperoleh skor $\geq 75$ dan tuntas secara klasikal jika seluruh kelas $\geq 75 \%$ diantara siswanya sudah tuntas belajar.

Observasi dipergunakan untuk mengumpulkan data tentang keaktifan siswa dalam proses belajar mengajar dengan menggunakan lembar observasi yang sudah disiapkan sehingga pengamat tinggal memberi tanda contreng $(\sqrt{ })$ pada lembar observasi. Dalam hal ini pengamatan dilakukan terhadap proses belajar mengajar yang berlangsung selama kegiatan penelitian. Pengamatan yang digunakan pada penelitian ini menggunakan rentang skor 1 sampai 4, dan ada 6 indikator yang akan diamati dalam pengamatan keaktifan ini. Untuk mengetahui kategori keaktifan siswa dari data penelitian, maka dilakukan uji kecenderungan dengan menggunakan rata-rata ideal $\left(\mathrm{M}_{\mathrm{i}}\right)$ dan standar deviasi $\left(\mathrm{SD}_{\mathrm{i}}\right)$ dengan menggunakan rumus yang dikemukakan oleh Arikunto dalam Hartono (2007:46). Dari harga-harga Mi dan SDi dari setiap variabel dapat diklasifikasikan dengan kriteria seperti yang dikemukakan oleh Arikunto dalam Hartono (2007:46) sebagai berikut :

$\begin{array}{ll}\text { Mi + 1,5 SDi s/d ke atas } & =\text { Tinggi } \\ \text { Mi s/d (Mi + 1,5 SDi) } & =\text { Cukup } \\ \text { Mi s/d (Mi - 1,5 SDi) } & =\text { Kurang } \\ \text { Mi - 1,5 SDi s/d ke bawah } & =\text { Rendah }\end{array}$

\section{Hasil dan Pembahasan}

Penelitian ini dilakukan dalam dua siklus dimana pada setiap siklus dilakukan dalam 2 pertemuan. Setiap siklus dilakukan dengan 4 tahapan yaitu: perencanaan (planning), pelaksanaan (acting), pengamatan (observing), dan refleksi (reflecting). Pelaksanaan pembelajaran pada setiap pertemuan meliputi 3 tahapan kegiatan yaitu kegiatan awal, kegiatan inti dan kegiatan penutup. Pembelajaran dilakukan untuk mengetahui nilai keaktifan dan hasil belajar siswa.

Pada pertemuan pertama di siklus I dilakukan pembelajaran dengan menerapkan model pembelajaran LSQ sesuai dengan langkah-langkah yang telah direncanakan didalam RPP dan selama pembelajaran berlangsung peneliti mengamati keaktifan siswa. Dan pada pertemuan kedua siklus I, siswa diberikan soal tes yang terdiri dari 20 soal. Setelah itu, Peneliti melakukan analisis data dari pengamatan keaktifan dan nilai hasil 
belajar yang di peroleh pada siklus I, sebagai dasar peningkatan keaktifan dan hasil belajar siswa pada siklus selanjutnya.

Dengan melihat hasil pengamatan keaktifan dan tes hasil belajar siswa pada siklus I, Setelah melaksanakan tindakan siklus I maka diadakan refleksi. Refleksi ini diadakan pada akhir siklus I. Dalam pelaksanaannya, refleksi dilakukan bersama guru bidang studi Ilmu Statika Bangunan. Hal ini dilakukan untuk mengkaji pembelajaran yang telah dilakukan pada siklus I. Hasil refleksi mengungkapkan, ternyata terdapat kelemahan - kelemahan diantaranya: (a) Sebagian siswa belum terbiasa dengan kondisi belajar yang mengarah pada model pembelajaran LSQ. Hal tersebut disebabkan karena selama ini guru hanya memberi pelajaran dengan metode ceramah lalu memberikan tugas untuk dikerjakan siswa. (b) Sebagian siswa belum memahami langkahlangkah LSQ secara utuh dan menyeluruh. Hal ini dapat dilihat dari hasil penelitian pada siklus I rata-rata keaktifan siswa hanya mencapai 67,23 dengan jumlah siswa yang memiliki kriteria nilai tinggi adalah 4 orang $(18,18 \%)$, kriteria nilai cukup 10 orang $(45,45 \%)$, kriteria nilai kurang 5 orang $(22,73 \%)$, dan kriteria nilai rendah 3 orang $(13,64 \%)$. Ini menunjukkan bahwa belum mengalami peningkatan pada keaktifan siswa. (c) Jumlah siswa yang tuntas belajar sesuai dengan standart nilai KKM adalah 13 orang, dan terdapat 9 siswa yang dinyatakan tidak tuntas dan berdasarkan hal tersebut presentase kelulusan adalah $64 \%$ dengan nilai rata-rata hasil belajar yaitu 69,09 (belum tuntas). (d) Ketika diawal pembelajaran Learning Start With A Question diterapkan terjadi keributan kecil karena siswa belum dapat terkontrol terutama ketika pembagian kelompok berlangsung.

Berdasarkan analisis proses pelaksanaan model pembelajaran LSQ pada siklus I, kegiatan pembelajaran pada siklus I terlihat belum optimal. Berdasarkan temuan-temuan yang telah dipaparkan, peneliti memutuskan melaksanakan tindakan perbaikan guna mencapai ketuntasan belajar siswa. Tindakan perbaikan yang akan diterapkan pada pembelajaran siklus II untuk menutupi kekurangan yang terjadi pada siklus I adalah :

a. Merencanakan ulang proses pembelajaran dengan berdiskusi kepada guru mengenai indikator yang belum tercapai yaitu untuk keaktifan indikator yang belum tercapai adalah sebagian siswa belum berani untuk mengajukan pertanyaan, memberikan pendapat, dan membuat kesimpulan.

b. Guru dengan intensif memberi pengertian kepada siswa kondisi belajar dan membantu siswa yang belum memahami langkahlangkah pembelajaran dengan menggunakan model LSQ.

Pada pertemuan pertama di siklus II dilakukan pembelajaran dengan menerapkan model pembelajaran LSQ sesuai dengan langkah-langkah yang telah direncanakan didalam RPP yang sudah diperbaiki dan selama pembelajaran berlangsung peneliti mengamati keaktifan siswa. Dan pada pertemuan kedua siklus II, siswa diberikan soal tes yang terdiri dari 21 soal. Setelah itu, Peneliti melakukan analisis data dari pengamatan keaktifan dan nilai hasil belajar yang di peroleh pada siklus II, sebagai dasar peningkatan keaktifan dan hasil belajar siswa pada siklus selanjutnya.

Setelah melaksanakan tindakan siklus II, kembali diadakan refleksi bersama guru bidang studi Ilmu Statika Bangunan. Refleksi ini diadakan pada akhir siklus II. Hasil refleksi siklus II mengungkapkan, bahwa kelemahankelemahan yang terjadi pada siklus I dapat diatasi

Hasil analisis pengamatan keaktifan siswa Siklus I setelah diterapkan model pembelajaran LSQ, diketahui bahwa keaktifan siswa dalam mata pelajaran Ilmu Statika Bangunan siswa belum optimal ini ditunjukkan dari nilai ratarata hasil pengamatan keaktifan siswa pada siklus I jumlah siswa yang memiliki kriteria nilai tinggi adalah 4 orang $(18,18 \%)$, kriteria nilai cukup 10 orang $(45,45 \%)$, kriteria nilai kurang 5 orang $(22,73 \%)$, dan kriteria nilai rendah 3 orang $(13,64 \%)$, dengan rata - rata keaktifan siswa 67,23 . Ini menunjukkan bahwa keaktifan siswa masih cenderung cukup dengan demikian hasil ini belum mengalami peningkatan maka keaktifan siswa harus ditingkatkan lagi. Untuk meningkatkan keaktifan siswa menjadi dapat dikatakan aktif perlu dilakukan peningkatan pada siklus II.

Hasil analisis data hasil belajar siswa Siklus I setelah diterapkan model pembelajaran LSQ, diketahui bahwa hasil belajar Ilmu Statika Bangunan siswa kelas X SMKN Binaan Provinsi Sumatera Utara belum mencapai ketuntasan klasikal 75\%, ini ditunjukkan dari nilai rata-rata hasil belajar siswa dalam penyelesaian soal-soal yang diberikan yaitu dari 22 jumlah siswa, 
yang tuntas belajar sesuai dengan standart nilai KKM (75) adalah 13 orang, dan terdapat 9 siswa yang dinyatakan tidak tuntas dan berdasarkan hal tersebut nilai rata-rata hasil tes pada siklus I untuk seluruh siswa adalah 69,09 sedangkan presentase kelulusan hanya $64 \%$.

Setelah dilaksanakan siklus II ternyata terjadi peningkatan terhadap hasil belajar Ilmu Statika Bangunan. Hal ini didapat dari hasil pengamatan keaktifan siswa dan hasil belajar siswa. Dari hasil pengamatan keaktifan didapat nilai rata-rata keaktifan siswa pada siklus II adalah 87,88 dengan jumlah siswa yang memiliki kriteria nilai tinggi adalah 18 orang $(81,82 \%)$, kriteria nilai cukup 4 orang $(18,18 \%)$, kriteria nilai kurang dan rendah tidak ada. Dalam hal ini jumlah siswa yang memiliki nilai keaktifan tinggi sudah lebih banyak dibanding siklus sebelumnya. Sehingga dapat dikatakan siswa sudah aktif dalam proses pembelajaran.

Analisis hasil belajar siswa yang dilakukan dengan menggunakan teknik tes. Ini ditunjukkan dari nilai rata-rata hasil belajar siswa dalam penyelesaian soal-soal yang diberikan yaitu dari 22 jumlah siswa yang tuntas belajar sesuai dengan standart nilai KKM $\geq 75$ adalah 22 orang. Berdasarkan hal tersebut nilai rata-rata hasil tes pada siklus II untuk seluruh siswa adalah 87,88 dan presentase kelulusan adalah $\geq 75 \%$.

Dari hasil penelitian dan ketercapaian indikator pada Siklus II di atas, maka dapat disimpulkan bahwa rata - rata nilai keaktifan siswa pada siklus II mengalami peningkatan yaitu 87,88 , dan jumlah siswa yang memiliki nilai keaktifan tinggi sudah jauh lebih banyak yaitu berjumlah 18 orang dengan persentase $81,82 \%$, maka siklus selanjutnya tidak perlu dilakukan lagi dan hasil belajar siswa juga mengalami peningkatan yaitu rata - rata hasil belajar siswa 87,88 dengan persentase siswa yang mendapat nilai minimal 75 mencapai $100 \%$ dari keseluruhan siswa. Hal ini menunjukkan bahwa siswa mencapai target minimal nilai 75 dari jumlah keseluruhan siswa dengan rata-rata komulatif kelas $\geq 75 \%$ (ketuntasan klasikal) maka siklus selanjutnya tidak perlu dilakukan lagi.

\section{Kesimpulan, Implikasi dan Saran \\ 5.1 Kesimpulan}

Berdasarkan hasil penelitian tindakan kelas (PTK) dapat disimpulkan sebagai berikut : a. Penerapan model pembelajaran Learning Start With A Question dapat meningkatkan Keaktifan siswa mata pelajaran Ilmu Statika Bangunan pada Siswa Kelas X Program Keahlian Teknik Gambar Bangunan SMKN Binaan Provinsi Sumatera Utara. Hal ini dapat diketahui dengan nilai rata-rata hasil observasi Keaktifan siswa yang mengalami peningkatan, yaitu pada siklus I dengan nilai rata-rata komulatif kelas 67,23 yaitu dengan jumlah siswa yang memiliki kriteria nilai tinggi adalah 4 orang $(18,18 \%)$, kriteria nilai cukup 10 orang $(45,45 \%)$, kriteria nilai kurang 5 orang $(22,73 \%)$, dan kriteria nilai rendah 3 orang $(13,64 \%)$, pada siklus II ratarata keaktifan siswa meningkat menjadi 87,88 dengan jumlah siswa yang memiliki kriteria nilai tinggi adalah 18 orang $(81,82 \%)$, kriteria nilai cukup 4 orang $(18,18 \%)$, kriteria nilai kurang dan rendah tidak ada.

b. Penerapan model pembelajaran Learning Start With A Question dapat meningkatkan hasil belajar Ilmu Statika Bangunan pada siswa Kelas X Program Keahlian Teknik Gambar Bangunan SMKN Binaan Provinsi Sumatera Utara. Hal ini dapat diketahui dengan nilai rata-rata hasil belajar siswa mengalami peningkatan, yaitu pada siklus I nilai rata-rata komulatif kelas 69,09 dengan Persentase siswa tuntas belajar 64\%, dengan jumlah siswa yang memiliki nilai sangat kompeten tidak ada, nilai kompeten 3 orang $(14 \%)$, nilai cukup kompoeten 10 orang $(45 \%)$, dan nilai tidak kompeten 9 orang (41\%), pada siklus II meningkat menjadi 87,88 dengan jumlah siswa yang memiliki nilai sangat kompeten 5 orang $(23 \%)$, nilai kompeten 12 orang (55\%), nilai cukup kompeten 5 orang (23\%), dan nilai tidak kompeten tidak ada, dengan Persentase kelulusan $\geq 75 \%$ dari keseluruhan jumlah siswa.

\subsection{Saran}

Setelah melihat hasil penelitian, pembahasan, dan kesimpulan maka peneliti memberikan saran sebagai berikut:

a. Bagi Kepala SMKN Binaan Provinsi Sumatera Utara, karena kegiatan ini sangat bermanfaat khususnya bagi sekolah, maka diharapkan mendukung pelaksanaan secara berkesinambungan sebagai referensi yang dapat digunakan oleh guru mata pelajaran lain. 
b. Bagi Guru, dalam kegiatan belajar mengajar guru diharapkan menjadikan model pembelajaran Learning Start With A Question sebagai suatu alternatif dalam mata pelajaran Ilmu Statika Bangunan untuk meningkatkan Keaktifan dan hasil belajar siswa. Guru diharapkan mampu menjadi fasilitator yang terus-menerus membimbing siswa dalam membangun sendiri pengetahuan dalam menyelesaikan permasalahan materi pembelajaran.

c. Bagi Siswa Model pembelajaran Learning Start With A Question ini dirancang untuk mengatasi kesulitan belajar siswa secara individual. Diharapkan siswa dapat menggali kemampuan individu yang dimiliki dan mengembangkan rasa kepercayaan diri. Dengan demikian siswa diharapkan memiliki keaktifan belajar yang tinggi di dalam menerima suatu materi pelajaran, hal ini akan berdampak positif bagi hasil belajar siswa itu sendiri.

\section{Daftar Pustaka}

Anton, M, Mulyono. 2001. Aktivitas Belajar. Bandung

Arikunto, Suharsimi. 2006. Dasar-Dasar Evaluasi Pendidikan. Jakarta : PT. Rineka Cipta.

Arikunto, Suharsimi. 2007. Penelitian Tindakan Kelas. Jakarta: Bumi Aksara.

Arikunto, Suharsimi. 2010. Prosedur Penelitian. Jakarta : Rineka Cipta

Dimyati \& Mudjiono (2009). Belajar dan Pembelajaran. Jakarta : Rineka Cipta

Djamarah, Syaiful Bahri dan Zain, Aswan.2006, Strategi Belajar Mengajar. Jakarta : Penerbit Rineka Cipta.

Hamalik, Oemar. 2004. Proses Belajar Mengajar. Jakarta : Bumi Aksara

Istarani. 2012. 58 Model Pembelajaran Inovatif. Medan : Media Persada

Kamus Besar Bahasa Indonesia. 2008. Jakarta : Gramedia Pustaka Utama.

Khoiru, Iff A., Sofan, A., \& Tatik, E. 2011. Strategi Pembelajaran Sekolah Terpadu. Jakarta : Prestasi Pustaka

Kunandar. 2009. Langkah Mudah Penelitian Tindakan Kelas Sebagai Pengembangan Profesi Guru. Jakarta : Rajawali Pers

Nurdin. 2009. Meningkatkan Hasil Belajar. Jurnal Administrasi digilib.unimed.ac..id/public
Sardirman, AM. 2009. Interaksi Belajar dan Mengajar . Jakarta: PT. Raja Grafindo Persada.

Sanjaya, Wina. 2006. Strategi Pembelajaran Berorientasi Standar Proses Pendidikan. Jakarta : Kencana Prenada Media

Sardiman. (2011). Interaksi dan Motivasi Belajar Mengajar. Jakarta: Rajawali

Slameto. 2010. Belajar dan Faktor - faktor yang Mempengaruhinya. Jakarta : Rineka Cipta

Syafura, Wirdayanti. 2014. Penerapan Strategi Pembelajaran Pelajaran Dimulai Dengan Pertanyaan (Learning Start With A Question) Untuk Meningkatkan Aktivitas dan Hasil Belajar Pada Kompetensi Ilmu Batu dan Beton SMK Negeri 2 Binjai Tahun Ajaran 2013/2014. Skripsi FT. UNIMED. Medan

Syah, Muhibbin. 2010. Psikologi Belajar. Jakarta : PT. Raja Grafindo Persada. 